\author{
AgNIESZKA ŚWIETEK \\ Pedagogical University of Krakow, Poland \\ WIKTOR Osuch \\ Pedagogical University of Krakow, Poland
}

\title{
Teacher Engagement in Poland: Research Contexts and Support Tool Proposals
}

\begin{abstract}
In the process of the effective management of business enterprises and educational institutions, in addition to other factors affecting their success, the involvement of leaders and employees proves to be the critical issue. Enterprises incur a considerable expenditure of time and work on managing and increasing the commitment of their employees, as opposed to the education sector. Effective school management and teacher involvement have a considerable impact on the quality of teachers' work, and this affects the level of education and upbringing of students. The authors of the study describe the involvement of the work of teachers in four contexts: their professional development, professional advancement system, burnout processes, and the assessment of the effectiveness of their work based their students' learning. Cooperation within the international Engagement \& Beyond project, aiming at developing a practical tool for school management, facilitates the process of understanding the main mechanisms of teacher engagement. The system will automatically adjust the tools for measuring and raising the level of teacher involvement, taking the form both of detailed surveys developed by psychologists and human resource specialists, and materials prepared at the diagnosed motivation level of each participant. School management will be able then to diagnose the level of involvement of employees and create an action plan appropriate to needs at both personal and organisational levels.
\end{abstract}

Keywords: burnout; Engagement \& Beyond; engagement in work; entrepreneurship

Received: 15 January 2020

Accepted: 3 August 2020

\section{Suggested citation:}

Świętek, A., Osuch, W. (2020). Teacher Engagement in Poland: Research Contexts and Support Tool Proposals. Przedsiębiorczość - Edukacja [Entrepreneurship - Education], 16(2), 25-37. doi: $10.24917 / 20833296.162 .2$

\section{Introduction}

Until recently, the subject of engagement at work was an underdeveloped area of human resource management and the psychology of work. In private companies, the concept of work commitment is of great importance. The theory of commitment is based on the 
belief that employee satisfaction with performed tasks brings benefits for the organisation: increased productivity, creativity, willingness to learn and lower absenteeism (Hakanen, Bakker, Schaufeli, 2006; Oleksa, 2013). Therefore, employees' involvement becomes a manifestation of their entrepreneurial competencies. The theory of commitment assumes that it can result in increased well-being of an individual, and is also 'prophylactic' against burnout. Until now, the concept of work commitment has been associated mainly with professional burnout - that it was a commitment that caused the burning out (Oleksa, 2013). Work engagement is understood as a positive state characterised by the energy of action (vigour) and commitment (dedication) to professional duties. Commitment is associated here with enthusiasm and a willingness to take on challenges (Hakanen, Bakker, Schaufeli, 2006).

The article covers the subject of the work involvement of Polish teachers - a professional group of significance for society. The level of teacher involvement and the method of managing staff in schools translates not only into the quality of teachers' work. It also strongly influences the level of education and upbringing of the students. In education, unlike in the corporate sector, little attention is paid to raising employee engagement. Previous studies on teacher involvement have most often focused on paths of professional advancement or professional burnout, followed by teachers' lack of commitment.

The purpose of the article is both theoretical and practical. The theoretical is to indicate the contexts of research on teachers' work involvement in Poland. The practical concentrates on the possibility of increasing the level of teachers' work involvement and improving the school management process by using the tools of the international project Engagement \& Beyond. For the research, two methods were applied: for the first goal, a survey of the educational literature was used, indicating the contexts and analysing the results of research on the work involvement of teachers in Poland. In order to achieve the second, Engagement \& Beyond project tools were analysed as well as the possibility of using them to increase the level of teachers' work commitment.

\section{Contexts of the research on teachers' work involvement in Poland}

Employee involvement is a widely discussed issue in the field of human resource management including theoretical considerations on commitment as well as empirical research on factors determining the level of commitment and measuring the level of involvement and its effects (Rakowska, Macik, 2016). The theoretical considerations led to the emergence of three concepts of commitment: employee attitude, behavioural involvement (employee behaviour) and commitment based on the mutual exchange of benefits between employees and the company (Juchnowicz, 2012). Researchers also make an essential distinction between job engagement versus organisation engagement (Sacks, 2006). The research conducted within the framework of these concepts concerns the preferred attitudes of employees towards work (Kahn, 1992), employees sharing organisational values and devotion to work (Watson, 2010), occupational burnout (Maslach, Schaufeli, Leiter, 2001; Welbourne, Andrews, S.B., Andrews, A.O., 2005) and personal fulfilment (Leiter, Maslach, 1998). Various tools to measure employee engagement are used in empirical research. The most recognised is the UWES (Utrecht Work Engagement Scale), built of 17 statements concerning: "energy/vigour", "commitment to work/dedication" and "engagement/absorption in work" (Seppälä et al., 2009). The respondents provide 
answers by determining the degree of compliance of each statement with their situation, marking the answer on a seven-point scale (from 6 - always to 0 - never) (Kulikowski, Madej, 2013; Seppälä et al., 2009).

The advanced state of research on employee involvement in research on management does not translate into its state and quality for the involvement of professional teachers. Contrary to the corporate sector, Polish schools pay very little attention to researching and improving human resource management processes, including increasing employee engagement. Meanwhile, at school, as in any organisation, the critical factor determining the quality of work and the results achieved are the staff and their competencies. Among the various factors influencing the involvement of teachers in their work, only some of its aspects are examined in the Polish academic literature. The survey shows that this literature does not explicitly deal with the issue of teachers' work involvement; hence the authors' article lacks a classic literature review. Teacher involvement, though not defined, occurs in detailed studies by various authors and is considered in four contexts: professional development, teacher promotion system, professional burnout and the effectiveness of teachers' didactic work measured most often with an indicator called Educational Added Value (EWD - Edukacyjna Wartość Dodana) (Maslach, Jackson, Leiter, 1996; Pyżalski, Merecz, 2010; Szkolak, 2013).

\section{Commitment and professional development}

The issue of teacher involvement in their work in Polish literature is most often considered in the context of professional development (Szkolak, 2013). A developing teacher is a person who continually expands and updates all areas of knowledge, acquires new competencies and increases the effectiveness of work throughout a professional career. Taking up improvement activities confirms teachers' professional ambitions and aspirations for professionalism in various forms and areas (Szkolak, 2013). While working with a student, the teacher discovers and recognises not only the student's but also their own development possibilities. Developing professional competencies and building authority on this basis is a necessary condition for improving the quality of education and upbringing of young people. The results of research confirm the involvement of Polish teachers in recent years in professional development. In the study by E. Kochanowska (2016), every respondent out of 145 teachers in early childhood education declared their commitment to improving their professional competencies. The most common forms of professional development were training sessions of the 'pedagogical council' and workshops organised at school (91\% of respondents), related to their (usually) obligatory character and convenient time and place. The contribution among the surveyed teachers of institutional forms of professional development, such as postgraduate studies and courses was also high and amounted to nearly $80 \%$ of teachers. Approximately $87 \%$ of the respondents participated in workshops organised outside the school, and $64 \%$ attended methodological conferences (Kochanowska, 2016).

Involvement is also confirmed by the results of research conducted among teachers working at higher levels of education. Among the lower secondary school teachers surveyed by D. Piróg (2012) as many as 97\% declared taking advantage of various formal and informal forms of professional training confirmed by the fact that the respondents consider it to be effective. Those teachers critically analysed the training system and stated 
that professional development had a slightly more than a moderate impact on their work efficiency. The highest positive impact on the effectiveness of their work was subject methodology as well as the implementation of new curriculum reforms, and working with a student with special educational needs (Piróg, 2012). The most numerous group of respondents (almost 90\% of teachers) indicated an intellectual motive for professional development just because they felt they needed to expand their knowledge and skills to improve the quality of their didactic, educational and caring work concerning updating understanding and pedagogical and methodological skills. The teachers surveyed by Piróg (2012), while citing motives of professional development, primarily indicated pragmatic motives such as gaining new qualifications to "secure and strengthen" their position in the workplace ( $80 \%$ of respondents). For almost $19 \%$ of teachers, it was also about completing professional qualifications (Piróg, 2012). Consequently, the motivations for teachers to improve their qualifications also resulted from the real risk of losing their jobs, especially if they are qualified to teach only one school subject.

Teachers' involvement in forms of training, enabling them to teach other school subjects seems to be an inevitable and effective method of meeting these challenges (Piróg, Jania, 2014). The study conducted by the co-author of this study (Osuch, 2018) shows that currently postgraduate studies are chosen by teachers almost exclusively to gain additional qualifications, e.g. to teach another subject, and not to supplement knowledge or acquire additional competencies. In recent years, the primary motive for undertaking postgraduate studies was the need to fill a post at the school where they had worked so far. An additional motive for taking them up was their interest in the subject, often manifested over many years, but connected with the need to obtain additional qualifications (Osuch, 2018). Such a situation must lead to reflection on what to do with the teacher training process.

Apart from the factors that determine the necessity for further education for teachers in Poland, there are also those of a transnational nature: fast social and economic changes, as well as the progressive development and increasing role of modern technologies in the didactic process. As a result, the need to acquire new competencies grows, above all gaining the ability to work in multicultural and diverse groups, possessing the ability to cooperate with the local social environment, and incorporate information and communication technologies into students' everyday lives (Sielatycki, 2008).

\section{Commitment and level of teachers' professional promotion}

The second context of the research on teacher involvement covered in Polish academic literature is the system of professional promotion in the Polish education system. The development of a new teacher's professional promotion with different levels was one of the leading new aspects introduced with the reform of education. The purpose of this change was to increase quality and work efficiency, and motivation to raise qualifications, give a sense of professional and life stability, and raise the social prestige of the teaching profession. The four-level promotion scale was correlated with remuneration and privileges, and obtaining a higher level was linked to an appropriate qualification and examination procedure. The new system increased the teachers' professional development. However the most important reason for raising qualifications, according to the results of R. Pawlak's research (2005), was the desire to increase earnings (declared by $44 \%$ of teachers), and to a lesser extent, personal ambition (29\%) or developing understanding (24\%). 
There is also a negative aspect of the existing teachers' professional promotion system, which is the decline in professional development after achieving the highest level and the highest salary (Pawlak, 2005). Teachers' salaries in Poland are meagre (Table 1), and this prompted teachers in 2019 to proclaim the first mass strike of this professional group in many years. After a symbolic pay rise, teachers still earn relatively little. Since 1 September 2019, a full-time probationary teacher has received a basic salary of PLN 2782 gross, and a teacher with the highest level PLN 3817 gross. Even if teachers increase their salary by doing overtime and additional duties, it remains unattractive compared to the earnings in the modern labour market. Such a teacher receives a much lower salary than the average salary in the private sector which, according to the Central Statistical Office, in the fourth quarter of 2019 amounted to PLN 5125 gross (Komunikaty i obwieszczenia Prezesa GUS, 2019).

Table 1. Teachers' salaries in 2018-2019

\begin{tabular}{|l|c|c|}
\hline \multicolumn{1}{|c|}{ Teacher's professional level } & $\begin{array}{c}\text { Earnings in 2018 } \\
\text { (gross, in PLN) }\end{array}$ & $\begin{array}{c}\text { Earnings from } \\
\text { 1 September 2019 } \\
\text { (gross, in PLN) }\end{array}$ \\
\hline Probationary & 2417 & 2782 \\
\hline 'Contract' & 2487 & 2862 \\
\hline 'Appointed' & 2681 & 3250 \\
\hline 'Chartered' & 3317 & 3817 \\
\hline $\begin{array}{l}\text { *for comparison: average gross earnings in the } \\
\text { private sector }\end{array}$ & 4611 & 5125 \\
\hline
\end{tabular}

Source: author's study based on data from the Ministry of National Education (MEN) and the Central Statistical Office (GUS)

This issue was highlighted in the document Poland 2030. Development Challenges (Polska 2030..., 2009: 267), which emphasises the critical impact of the quality of teachers' work on student performance. One of the essential priorities in education is a change to the ineffective system of teachers' professional promotion and remuneration, and connecting it with an assessment of work quality. Currently, teachers' increased involvement in work is noticeable during the promotion period.

\section{Commitment and burnout}

The opposite of commitment is burnout, usually defined as a syndrome of exhaustion, cynicism, and reduced professional effectiveness (Maslach, Jackson, Leiter, 1996). Exhaustion refers to the feelings of tension and chronic fatigue resulting from being overloaded with work. Cynicism (depersonalisation) is an indifferent or distant attitude towards work, and towards the people one works with, loss of interest, as well as emotional feelings towards the duties performed. Finally, a decline in professional effectiveness harms a feeling of having competencies and achieving professional success in general or in a particular workplace.

The leading cause of burnout is an excessive workload which is higher among teachers than in other professions. Even though the obligatory weekly contact time for teachers is 18 hours, the number of administrative tasks, time spent on numerous pieces of training, 
teaching councils, professional development and self-education, and finally preparation for classes, often exceed the statutory 40 hours of work per week. Most of society is unaware of the additional duties teachers have, seeing only the benefits of a daily "short" stay at school and long holidays. Such "common" beliefs (especially commented on the internet) do not contribute to the reduction of occupational burnout.

Moreover, social expectations towards teachers steadily increase. In addition to professionalism, methodological modernity and updating the substantive knowledge of the subject taught, they are expected to individualise the education process and to be more involved in cooperation with the local community and parents. It is believed that a teacher is not the only one to educate students; parents and other members of local communities are valuable and not always used sources of knowledge (Fullan, 2001). Teachers are aware of the high expectations set for them. The research by J. Pyżalski and D. Merecz (2010) shows that the majority of Polish teachers (86\%) assess their work environment as more burdensome than for other professions. There are no real ways to counteract burnout in the form of tools to increase motivation, for example, to reward teachers' achievements decently. The only financial tools at the disposal of headteachers are the so-called "incentive pay" and "principal's awards". In most state schools, they are very low and awarded by the management (often on a discretionary basis) from local government funds on the grounds of specific criteria. These resources are usually insufficient and disproportionately low compared to the level of teachers' involvement in their work.

Research by M. Zahorska and D. Walczak (2009) provides interesting data on the involvement of teachers indicating that despite professional burnout, most teachers would choose the same profession again. In in-depth interviews, teachers negatively assess the reform of education, their financial status, and the management of educational institutions. On the other hand, they assess very positively personal relationships with their students and their parents and other values of teaching, which make them want to continue working in the profession. This positive attitude of teachers (despite the inconveniences) is confirmed by research on Poles' satisfaction with work carried out by TNS OBOP (2010). They showed that people working in the educational sector (state schools, preschool education, universities, and educational support institutions) are much more satisfied with their work compared to those employed in other sectors (Pyżalski, Merecz, 2010). Based on an analysis of all the cited research results, it can be concluded that teachers assess the formal aspect of their work and educational institutions poorly, but value the informal world of the teacher-student relationship (Zahorska, Walczak, 2009).

\section{Commitment and educational added value}

The last issue directly related to teachers' involvement is the assessment of the effectiveness of their work. Measuring the effectiveness of teachers' work (especially those on various promotion levels) and creating an objective system for rewarding and distinguishing the best teachers is complicated and problematic. External exams play a significant role in increasing the involvement of teachers in schoolwork, resulting in the improvement of the school's working methods, mobilisation of the teaching staff and the need for systematic and effective didactic work for the full implementation of the educational objectives contained in the core curriculum. Exams are held at the end of each level of education. Preparation for external exams and the importance of the results (e.g. in the recruitment 
process for the next stage of education) strengthens the current motivation of students to learn and increases the involvement of teachers (Rappe, 2013). One of the primary measures of teacher's work effectiveness, measured based on the increase in students' knowledge, is the educational added value (Polish EWD). According to its assumptions, it allows the diversity of schools due to the level of knowledge and skills of students to be taken into account. In order to calculate the indicator, the results of students from external examinations after two consecutive educational stages are considered, e.g. the results of the lower secondary examination and the final upper secondary school exam (matura) are compared. Theoretically, this is a measure of students' progress. The results of the exams only inform about the level of students' achievements at school, and an educational added value calculated on that basis indicates the teacher's didactic activities. However, students' examination results also depend on their family background, ability and motivation at school. For evaluation purposes, indicators of learning outcomes (exam scores) and teaching effectiveness should both be taken into consideration. In the authors' opinion, educational added value (EWD) cannot be used to assess the level of involvement or quality of teachers' work (Central Examination Board, CKE website). However, EWD is often used to create rankings of schools which are taken into account by students while choosing the schools where they want to continue their education.

The international project Engagement \& Beyond major assumptions and goals of the project

The international project Engagement \& Beyond is carried out as part of the Erasmus+ program no. 2017-1-HU01-KA201-035998 (1.09.2017-31.08.2020). The project leader is EDUNET Alapítvány (Hungary), and the partners are Connect Media Ltd. (Hungary), Train'd Up Railway Resourcing Limited (UK), Euro-Trainings-Center ETC e. V. (Germany) and the Pedagogical University of Kraków. The Polish team working in the project included S. Kurek (PhD, Assoc. Prof.), W. Kilar (PhD), W. Osuch (PhD, Assoc. Prof.), T. Rachwał (PhD, Assoc. Prof.) and A. Świętek (PhD).

As a preliminary assumption, it was assumed that effective management and employee involvement is crucial for the efficient functioning of organisations both for large enterprises and educational institutions such as schools. In the education sector, the process of increasing employee engagement has received very little attention. It has not always been noticed that effective school management and strong teacher commitment to work for the benefit of the school may translate into a higher quality of teachers' work.

In the first phase of the project, the work of the international partners is aimed at developing a practical tool for headteachers to diagnose employee engagement. In addition to this, headteachers will be able to create an action plan appropriate to their needs. Its implementation will help increase the level of employee involvement on a personal and organisational level, but the primary beneficiaries of the project were the schools. The project involved a total of around 600 participants from different backgrounds in four project partner countries (Hungary, Germany, Poland, United Kingdom), including, besides headteachers, leaders of companies or departments, human resources (HR) specialists and teachers who were the largest group of project beneficiaries - approximately 480 of them. 
Tools for measuring and increasing the level of teacher involvement developed in the international project Engagement \& Beyond

As part of the project work, three tools were developed to measure and increase teacher engagement. These were a tool for diagnosing teachers' involvement in the form of a detailed questionnaire, a tool for increasing teachers' motivation in the form of motivating materials sent to teachers, and a tool for headteachers to analyse the level of teaching staff s motivation in the form of a platform.

The most important tool is a questionnaire that allows diagnosis of the level of teachers' involvement in two areas: school development and personal development. It is modelled on the tools used in research on management indicated earlier in "Contexts of teacher involvement research ...” of this study. The diagnostic questionnaire was created with the help of human resource specialists and psychologists. It consists of 86 statements concerning various aspects of teacher's work and school management (Table 2) that affect the level of teacher involvement. It assumes a distinction between the level of involvement in school development and self-development, and concerns various aspects and factors determining commitment: material working conditions, relations at school, the sense of appreciation of the work done, the quality of school management, division of responsibilities, professional development opportunities, opportunities for personal and educational development, the goals of the school and its importance for the community.

Table 2. Examples of statements included in the questionnaire diagnosing the level of teacher involvement and the scale of answers

\begin{tabular}{|c|c|c|c|c|c|}
\hline \multirow{8}{*}{ Statements } & \multicolumn{5}{|c|}{ I have enough time to rest outside of work. } \\
\hline & \multicolumn{5}{|c|}{ My current salary is adequate for the work performed. } \\
\hline & \multicolumn{5}{|c|}{ I understand what my superiors expect of me. } \\
\hline & \multicolumn{5}{|c|}{ My friends and colleagues appreciate my contribution to the work of my team. } \\
\hline & \multicolumn{5}{|c|}{ My supervisor takes my opinion into account. } \\
\hline & \multicolumn{5}{|c|}{ My supervisor judges my work based on its results. } \\
\hline & \multicolumn{5}{|c|}{ I am motivated by the progress of my students. } \\
\hline & \multicolumn{5}{|c|}{ The work I do contributes to the personal development of my students. } \\
\hline $\begin{array}{l}\text { Possible } \\
\text { answers }\end{array}$ & Definitely yes & Rather yes & $\begin{array}{l}\text { To a certain } \\
\text { degree }\end{array}$ & Not at all & \begin{tabular}{|l} 
I don't \\
know/I don't \\
want to \\
answer
\end{tabular} \\
\hline
\end{tabular}

Source: authors

The respondents provide answers on a four-point scale (Table 2). A questionnaire helps provide a detailed diagnosis of each project participant, in this case, the teacher who will receive information on the level of involvement in various areas of work as well as access to individualised motivating materials. The system that provides motivational materials is another essential tool, and the idea is based on the incentive solutions used in large international enterprises. Motivating materials are varied and are automatically adjusted to the diagnosed level of the participant's motivation. According to the assumptions of the project, the process of increasing teachers' motivation will take place through the use of motivating materials tailored to their needs, previously prepared by the project 
partners. Support for the level of motivation of project beneficiaries will last for the six months of using the motivational materials. The phase of using motivational materials also takes into account the elements of 'gamification', the 'ranking' of the proposed activities, proven in the corporate motivation systems.

The third tool developed within the project is a platform for analysing the level of motivation of teachers at school while maintaining full anonymity. By logging on to the platform, the headteacher obtains the opportunity to view collective assessments of levels of employee involvement which have been statistically developed (in the form of tables, charts - see Figure 1), as well as the ability to access a detailed analysis of various aspects

\section{My job gives me the opportunity for personal development}

\begin{tabular}{|c|c|c|c|c|c|}
\hline \multicolumn{6}{|l|}{ Answers } \\
\hline Definitely yes & Rather yes & $\begin{array}{c}\text { To a certain } \\
\text { degree }\end{array}$ & Not at all & $\begin{array}{l}\text { I don't } \\
\text { know/I don't } \\
\text { want to } \\
\text { answer }\end{array}$ & Total \\
\hline $1(6 \%)$ & $8(44 \%)$ & $8(44 \%)$ & $1(6 \%)$ & 0 & 18 \\
\hline \multicolumn{6}{|c|}{ 4. I have an influence on decisions at school } \\
\hline \multicolumn{6}{|l|}{ Answers } \\
\hline Definitely yes & Rather yes & $\begin{array}{c}\text { To a certain } \\
\text { degree }\end{array}$ & Not at all & $\begin{array}{l}\text { I don't } \\
\text { know/I don't } \\
\text { want to } \\
\text { answer }\end{array}$ & Total \\
\hline $1(6 \%)$ & $6(33 \%)$ & $10(56 \%)$ & $1(6 \%)$ & 0 & 18 \\
\hline
\end{tabular}

Figure 1. Example method of presenting the results of the diagnosis of teacher involvement available for analysis by the headteacher

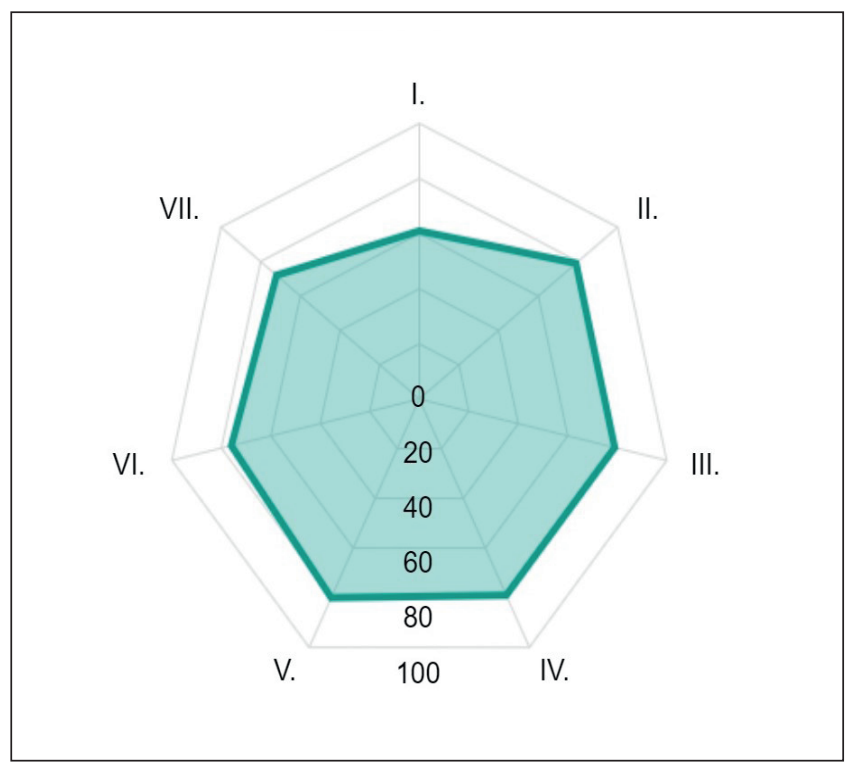

Source: authors based on fictitious data 
of the school's operation from the point of view of the teaching staff (e.g. assessment of teachers' influence on decisions made at school or opportunities for individual development). In contrast, the answers of individuals remain secret as teachers remain anonymous. Based on the information obtained on the platform, the headteacher has a more manageable task in terms of making decisions, the possibility of increasing the level of commitment of employees and improving the work of the school.

All the indicated tools for measuring and increasing the level of teacher involvement are considered innovative as for human resource management in education. They have been adapted to the needs of schools and teachers to become complete and universal tools that can be used in all types of school in Poland.

\section{Summary and conclusions}

The effectiveness of teachers' work influences the creation of new human capital and an increase in the quality of society as a whole. The level of knowledge and skills acquired by students to a large extent depends on the activity of teachers and the quality of their work. Consequently, it leads to an increase in the value of their human capital. Apart from the activity of the teaching team, the school management style has a significant influence on the quality and effectiveness of the educational process. School authorities should develop their own management approach, create conditions for teacher improvement, be able to engage teachers, and provide support for employees by taking care of their working conditions.

So far, no effective tools have been developed to measure the level of commitment or raise the involvement of teachers. The implemented system of professional promotion for teachers has not significantly increased their involvement. Teachers, after a period of increased activity in the course of the implementation of subsequent levels of professional promotion, no longer feel the need or motivation to be more active after reaching the highest level, and the level of earnings, regardless of position, years of work and achievements, leaves much to be desired. However, nothing has been done in recent years to overcome or resolve this neglect. The state of research into teacher involvement is highly unsatisfactory as its focus was on the process of professional burnout, and the proper diagnosis of how to motivate teachers and prevent professional burnout of this numerous and significant social group was not correctly diagnosed.

The issues presented here authorise the formulation of the following general conclusions:

- unlike enterprises, very little attention in Polish schools is paid to improve human resource management processes, including increasing employee engagement;

- research on teacher engagement focuses on the analysis of career advancement and occupational burnout (Maslach, Jackson, Leiter, 1996; Pyżalski, Merecz, 2010);

- there is an urgent need to develop tools to test the level of teacher involvement and implement improvements in schools;

- numerous studies show that the majority of Polish teachers (86\%) assess their work environment as more burdensome than for other professions (Pyżalski, Merecz, 2010). With low earnings, they continuously improve their qualifications (Piróg, 2012), and one of the measures of the effects of their work includes the educational added value (EWD); 
- the Engagement \& Beyond project has attempted to open up a new area of research into the work of teachers and to develop tools to measure and raise the level of teacher involvement at work.

Further research into teacher involvement and human resource management in schools seems necessary, as well as designing and implementing tools for increasing teachers' involvement in their work and improving the management process in schools.

\section{References}

Fullan, M. (2001; 2020, 2 Jaunary). Implementing Change at the Building Level. Paper prepared for W. Owings, L. Kaplan (eds.) Critical and Emerging Issues in Educational Leadership. Retrieved from: http://michaelfullan.ca/wp-content/uploads/2016/06/13396045300.pdf

Hakanen, J.J., Bakker, A.B., Schaufeli, W.B. (2006). Burnout and work engagement among teachers. Journal of School Psychology, 43, 495-513.

Juchnowicz. M. (2012). Zaangażowanie pracowników. Sposoby oceny i motywowania. Warszawa: PWE.

Kahn, A.W. (1992). To Be Fully There: Psychological Presence at Work. Human Relations, 45, 321-349.

Kochanowska, E. (2016). Zaangażowanie nauczycieli edukacji elementarnej w doskonalenie kompetencji zawodowych. Komunikat z badań. Zeszyty Naukowe Wyższej Szkoły Humanitas. Pedagogika, 13, 195-207.

Komunikaty i obwieszczenia Prezesa GUS. Archiwum z 2019 r. (2020, 2 January). Retrieved from: https:// stat.gov.pl/sygnalne/komunikaty-i-obwieszczenia/18,2019,kategoria.html

Kulikowski, K., Madej, M. (2013). Zaangażowanie w pracę - problemy z pomiarem. Problemy Zarządzania, 45(1), 99-112.

Leiter, M.P., Maslach, C. (1998). Burnout. In: H. Friedman (ed.), Encyclopedia of Mental Health. New York: Academic Press, 347-357.

Maslach, C., Jackson, S.E., Leiter, M.P. (1996). Maslach burnout inventory manual. Palo Alto: Consulting Psychologists Press.

Maslach, C., Schaufeli, W.B., Leiter, M.P. (2001). Job Burnout. Annual Review of Psychology, 52(1), 397422.

Oleksa, K. (2013). Wypalenie zawodowe, zaangażowanie i satysfakcja z pracy u osób wykonujących zawody społeczne. Debiuty Naukowe Studentów Wyższej Szkoły Bankowej, 13, 109-124.

Osuch, W. (2018). Kompetencje nauczyciela geografii w świetle reformy systemu edukacji - potrzeba czy konieczność, czego powinniśmy się nauczyć, aby nowocześnie uczyć?. Annales Universitatis Paedagogicae Cracoviensis. Studia Geographica, 268(12), 26-38.

Pawlak, R. (2005). Dylematy polityki edukacyjnej wobec nauczycieli. Polityka Społeczna, 10, 12-13.

Piróg, D. (2012). Poziom zainteresowania pracą w zawodzie nauczyciela wśród studentów geografii. Prace Komisji Edukacji Geograficznej PTG, 2, 194-210.

Piróg, D., Jania, R. (2014). Dokształcanie i doskonalenie zawodowe nauczycieli geografii jako instrument dostosowania się do aktualnych wyzwań rynku pracy. Annales Universitatis Paedagogicae Cracoviensis Studia Geographica, 4, 72-83.

Polska 2030. Wyzwania rozwojowe. (2009; 2020, 2 January). Warszawa: Zespół Doradców Strategicznych Premiera RP. Retrieved from: http://kigeit.org.pl/FTP/PRCIP/Literatura/001_PL_2030_wyzwania_rozwojowe.pdf

Pyżalski, J., Merecz, D. (2010). Psychospołeczne warunki pracy polskich nauczycieli. Pomiędzy wypaleniem zawodowym a zaangażowaniem. Kraków: Wydawnictwo Impuls.

Rakowska, M., Macik, R. (2016). Zaangażowanie pracownika a satysfakcja z pracy - modelowanie zależności z wykorzystaniem PLS-SEM. Przegląd Organizacji, 5, 48-58. 
Rappe, A. (2013). Opinie nauczycieli i dyrektorów o systemie egzaminów zewnętrznych na podstawie badań prowadzonych przez zespół EWD. Gniezno: Okręgowa Komisja Egzaminacyjna w Krakowie, Instytut Badań Edukacyjnych, XIX Konferencja Diagnostyki Edukacyjnej, 254-267.

Sacks, A.M. (2006). Antecedents and Consequences of Employee Engagement. Journal of Managerial Psychology, 21(7), 600-619.

Seppälä, P., Mauno, S., Feldt, T., Hakanen, J., Kinnunen, U., Tolvanen, A., Schaufeli, W. (2009). The Construct Validity of the Utrecht Work Engagement Scale: Multisample and Longitudinal Evidence, Journal of Happiness Studies, 10, 459-481.

Sielatycki, M. (2008). Kompetencje nauczyciela w Unii Europejskiej. In: K. Sujak-Lesz (ed.), Kształcenie nauczycieli w szkole wyższej. Wybrane zagadnienia. Wrocław: Oficyna Wydawnicza Atut, 13-21.

CKE. (2019, 13 December). Co to jest EWD?. Retrieved from: http://ewd.edu.pl/wskazniki/matura/coto-jest-ewd/

Szkolak, A. (2013). Mistrzostwo zawodowe nauczycieli wczesnej edukacji. Istota, treść, uwarunkowania. Kraków: Wydawnictwo Attyka.

Watson, T. (2010). Committed to Health: A Large Hospital Network Links Employee Engagement with Patient Satisfaction to Maximise Competitive Strength. Retrieved from: http://www.towerswatson. com/assets/pdf/1549/Healthcare_Case-Study_4-12.pdf

Welbourne, T.M., Andrews, S.B., Andrews, A.O. (2005). Back to Basics: Learning about Employee Energy and Motivation from Running on my Treadmill. Human Resource Management, 44(1), 55-66.

Zahorska, M., Walczak, D. (2009). O osobliwości nauczycielskiej duszy. In: A. Nowak, K. Winkowska-Nowak, L. Rygielska (eds.), Szkoła w dobie Internetu. Warszawa: Wydawnictwo Naukowe PWN, $55-74$.

Agnieszka Świętek, PhD in geography, graduated from the Pedagogical University of Krakow, MSc in geography, specialisation in Entrepreneurship and spatial planning. Associate professor at the Pedagogical University of Krakow, Institute of Geography. Her research interests focus on two different research themes: the education in the field of geography and entrepreneurship, in particular the process of starting up own business, young people entering into the labour market and the quality of life of Roma in Poland.

ORCID: https://orcid.org/0000-0002-5049-6476

\section{Address:}

Uniwersytet Pedagogiczny im. Komisji Edukacji Narodowej w Krakowie

Instytut Geografii

Katedra Badań nad Edukacją Geograficzną

ul. Podchorążych 2

30-084 Kraków, Polska

e-mail: agnieszka.swietek@up.krakow.pl

Wiktor Osuch, PhD, associate professor at the Pedagogical University of Krakow, Institute of Geography, Department of Didactics of Geography. Born in Krakow and graduated from the Faculty of Geography at the Pedagogical University of Krakow, Associate Professor in the field of social sciences. He is a university lecturer employed in the Didactics of Geography Department, Institute of Geography at the Pedagogical University of Krakow. Teaching Duties (courses taught): Geography education - Didactic geography in lower and upper secondary schools, Interpersonal communication, Student's teaching practice, Concepts of the education internships, Didactic geography seminar. Research Interest in the field of didactic geography: teacher's education, teaching practice, geography teacher's professional competencies, key competencies, teaching methods, geography curriculum and school-books.

ORCID: https://orcid.org/0000-0002-1889-3762 


\section{Address:}

Uniwersytet Pedagogiczny im. Komisji Edukacji Narodowej w Krakowie Instytut Geografii

Katedra Badań nad Edukacją Geograficzną

ul. Podchorążych 2

30-084 Kraków, Polska

e-mail: wiktor.osuch@up.krakow.pl

The article is based on the results of the "Engagement \& Beyond" (E\&B) project (2017-1-HU01-KA201-035998), co-funded by the Erasmus + Programme of the European Union.

The European Commission's support for the production of this publication does not constitute an endorsement of the contents, which reflect the views only of the authors, and the Commission cannot be held responsible for any use which may be made of the information contained therein.
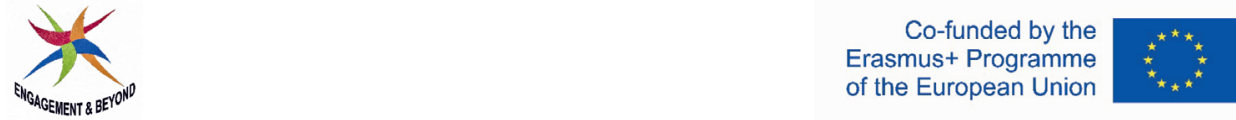